\title{
Factors Affecting Secondary School Students' Academic Achievements in Chemistry
}

\author{
Aimable Sibomana \\ African Center of Excellence for Innovative Teaching and Learning Mathematics \\ and Science (ACEITLMS), \\ University of Rwanda - College of Education (UR-CE), Republic of Rwanda \\ https://orcid.org/0000-0002-9452-9145 \\ Claude Karegeya \\ School of Education, University of Rwanda - College of Education (UR-CE), \\ Republic of Rwanda \\ https://orcid.org/0000-0002-5855-7122
}

John Sentongo

Department of Science, Technical and Vocational Education (DSTVE), Makerere University, College of Education and External Studies, Kampala, Republic of Uganda https://orcid.org/0000-0002-8693-2639

\begin{abstract}
Secondary school students continue to consider chemistry as difficult to learn and develop a negative attitude towards it. This leads to low achievement in the subject and reduces their interest. Studies on students' achievement in chemistry have been conducted and different instructional strategies of teaching and learning have been provided. Nonetheless, there are persisting misconceptions and factors that hinder the achievement of students, even after the implementation of suggested strategies. By applying innovative teaching approaches as remedial to teaching and learning barriers, students' achievement may be improved; and the retention of the learned material may be enhanced. In this study, we conducted a literature search to collect any related literature. Sixtyone studies were obtained; some of them were not related to our investigation; and those which did not answer the research question were excluded, we remained with 13 studies. The selection of studies was based on year of publication, and language. These studies were published in English and between 2011 and 2021. Consequently, this review highlights the influence of teaching methods on students' achievements, updating teachers on the factors affecting students' achievements in Chemistry, misconceptions in chemistry instruction, and ways for remedying those misconceptions, as well as methods for improving students' academic achievements.
\end{abstract}

Keywords: achievement; chemistry education; constructivism; innovative teaching methods; misconception in chemistry 


\section{Introduction}

Chemistry students' academic achievement refers to their educational accomplishment at school, and it is characterized by score or percentage (Ajayi, 2017a). As an indicator, academic achievement is an important milestone for learners; it is the vital goal of learning Chemistry the world over. However, learners in an identical set of academic situations vary in their scholastic accomplishment (Imomotimi, 2013). Learning is a process of concept formation and positive permanent change; it is not just the acquisition of correct responses (Broman et al., 2018). Studies have indicated the challenges associated with quality Chemistry education. For example, Akram et al. (2017), Bunujevac and Durisic (2017), Imomotimi (2013), and Tümay (2016) revealed the challenges of effective Chemistry teaching, including attitude and learning experiences; nonprofessionalism; time constraints; class size; conditions of service, or remunerations, laboratory adequacy; learning style, parental involvement; examination malpractices and the choice of a subsequent career.

However, according to Ajayi (2017b) a Chemistry teacher aimed at changing the instruction from lecture to innovative learning strategies, such as learning cooperatively, using concept maps by making improvised materials where there is no standard equipment, would not necessarily succeed in teaching Chemistry

On the other hand, one of the roles of instruction to any nation is to produce trained persons with competencies in different fields, and not to consider chemistry to be difficult to teach and study (Dwyer \& Childs, 2017; and Mahdi, 2014). The problem of misconceptions and low achievements in Chemistry, have also been highlighted by several researchers, such as Adu-Gyamfi et al. (2020), Ajayi (2017a), Ejidike and Oyelana (2015), Graulich (2015), Hanson (2017), Luoga et al. (2013), Mari and Gumel (2014), and O’Dwyer and Childs (2015).

Effective chemistry teaching that involves learners' active engagement when properly used by teachers leads to socio-economic development, as well as developing countries embarked on programs that support the development of science education at secondary and higher educational levels (Mahdi, 2014). Flexible teachers need to employ innovative teaching methods directly to a conducive classroom environment, and which adjust the content to learners with different backgrounds and talents (Sibomana et al., 2021). Academic achievement relies hugely on teaching and learning, as well as on the fulfilment of the aims of education. Instruction dominated by lecturing does not inspire students to learn; and no single teaching method fits all (Tümay, 2016); whereas good teaching methods influence students' interest in the topic; since good teachers consider students' perspectives by managing and helping them to change their misconceptions about the subject. Consequently, strategies of teaching are attractive; they shape students' attitudes positively towards the subject; and it is the role of the facilitator (teacher) to manage such factors(Ejidike \& Oyelana, 2015; Farzaneh \& Nejadansari, 2014).

Furthermore, using one teaching method is not good enough; because students have different learning styles; and they are likely to develop attention when the 
teaching approaches stimulate their intention to know (Okwuduba, 2018). In this regard, Chemistry teachers could apply different techniques, in order to optimize students' achievement by involving them in learning activities and by arranging concepts to be taught from simple to complex, so as to facilitate them in understanding the abstract or complex concepts; since if not, students tend to memorize what they are taught without understanding it (Yusuf, 2014).

Some teachers adopt a traditional teaching approach, which is teacher-centered; while the students are only a mute and passive audience. Consequently, the previous knowledge is not properly activated (Akram et al., 2017). Ineffective teaching methods lead to students' low achievement in Chemistry; and the World Bank report indicated their low achievements, while doing the end cycle examinations among Sub-Saharan Africa, where large numbers of African youths lack skills and the necessary knowledge to qualify for jobs and for post-secondary courses in STEM, which would prepare them for well-paying jobs (World Bank, 2016).

For learners to actively construct meaning, there are various instructional approaches that should be adopted by Chemistry teachers. Nkemakolam et al. (2018) opine that no approach can be regarded as the best for every teaching situation. According to Ejidike and Oyelana (2015) and Tenaw (2015), Chemistry teachers should be aware of certain general rules, which facilitate the selection of appropriate approaches for developing skills for students. Such rules for selecting approaches for teaching a Chemistry lesson include consideration of the student's age, their previous knowledge of the topic, and their general ability, among other issues.

Good teaching methods influence students' interest in the topic (Tolsdorf et al. 2018); and learning is a societal advancement that includes language, everyday situations, communication, and teamwork among learners, who are considered to be central in the learning process, which is enhanced by assimilation and accommodation (Amineh \& Asl, 2015; Kara, 2018).

Studies have reported that different innovative teaching approaches improve students' achievement in Chemistry, such as cooperative learning; peer teaching, (Amedu and Gudi, 2017; Gagne's learning hierarchy, Yusuf's (2014); inquiryteaching strategy, Harcourt (2017); computer simulations, Nkemakolam et al. (2018); problem-solving instructional strategies, (Shadrec et al. 2018); Tetrahedral in-zone of Proximal Development (T-ZPD), Yitbarek (2011. Context-based learning approaches (CBL) also improve students' interest and learning outcomes by the clear linkage between Chemistry, society, research and practice (Vogelzang et al., 2020).

Learners' conceptual understanding was also identified to be developed by the use of the jigsaw model of cooperative learning; and consequently, this also enhances students' achievement in Chemistry (Mari \& Gumel, 2014). Although most innovative teaching approaches have been reported to be significant in comparison with traditional approaches (lecture methods, in most cases) being 
applied by some chemistry teachers; there are inconsistent extents regarding the effects of different teaching methods on learners' scholastic accomplishment in Chemistry, depending on the sample and the methods used. For instance, the study of Yüksel (2014) with the sample of 252 students in a vocational high school, found that the academic achievement in Chemistry course was observed to be related with cognitive and affective characteristics that comprise the nature of students.

Research has shown difficulties in learning chemistry; and it is perceived to be a pertinent subject; but the students do not see themselves occupied in the field of Chemistry in their future life; others find it to be difficult to learn and teach; and they feel that they are ineffective when engaged in it (Graulich, 2015; Hanson, 2017; and Tümay, 2016).

Some of the conceptual areas of students' misconceptions are: Organic chemistry (O'Dwyer and Childs 2015); stoichiometry (Shadrec et al. 2018); chemical reactions (Stojanovska et al. 2012); chemical compounds, the oxidation-reduction concept, Adu-Gyamfi et al. (2020); electrochemistry, (Murniningsih et al. 2020); colligate properties (Luoga et al. 2013); hybrid orbitals' notation, (Farias 2017), chemical thermodynamics and kinetics, and chemical solutions (Broman et al., 2018).

The above views may differ from one person to another, depending on the learning environment. Taking organic chemistry as difficult to learn for students depends on its nature, like the three dimensions of thinking and the specific vocabulary to be used (Tenaw, 2015). The nature of Chemistry concepts and the technique of their representation (macroscopic, microscopic) conflict with the nature of science regarding their methods of teaching; what is taken by Organic Chemists for approval in their particular problem-solving is not similar to how students answer questions (there are no algorithms for solving problems in Organic Chemistry); but problem-solving depends more frequently on the mediating trends in reactivity, developing mechanisms to analyze chemical calculations (Graulich, 2015). One major cause of students' indifference towards Chemistry is the non-connectivity between Chemistry and one's personal life. Some students are incapable of associating Chemical concepts with everyday life; and when teachers introduce topics, the students then ask about the importance thereof in their lives (Hanson, 2017).

Students of dissimilar ages may have comparable misunderstandings that influence the way they understand complex concepts. The language can also enhance these misconceptions; as the meaning of a similar term in Chemistry may be different from the language applied in one's daily life (Üce \& Ceyhan, 2019). Similarly, some representations used in textbooks provide only descriptions of phenomena that have their strengths and limitations relative to some possible misconceptions (Graulich, 2015). Chemistry education aims at equipping students with a strong understanding of the discipline, in order to enable them to explain, predict and control nature (Tümay, 2016).

Future chemistry teachers need to be prepared to identify and handle inconsistencies in their classrooms, being involved more strongly in student- 
teachers' internships, in order to equip them with deep knowledge of their students' prior knowledge, on how to plan for their suitable learning outcomes (Tolsdorf et al. 2018). They should arrange lessons logically from simple to complex, using a variety of symbolic representations; and while assessing any problems, they should vary the questions, in order to measure all learning objectives and to plan for future instructions accordingly (Yitbarek, 2011).

A list of general indicators of qualified teachers includes an adequate understanding of the topic to teach with confidence, knowledge, and skills with a range of suitable and mixed teaching methods, as well as mastering the language of instruction. A qualified teacher is characterized by the capability to reflect on teaching practice and children's responses, ability to change teaching and learning methods, as a result of reflection, as well as the ability to generate and sustain an active learning environment, and not consider Chemistry as being too difficult to teach, as well as other science subjects (Mahdi, 2014). A teacher could also understand the curriculum and its determinations, particularly when improvement plans and new models of instruction are introduced. They could be characterized by overall competence, good self-esteem, and a firm commitment to the objectives of teaching. Furthermore, a qualified teacher should be able to communicate successfully, be conscientious, and able to apply individual discipline, to build good relationships with others, with the school, as well as with the community (Tenaw, 2015).

\section{The Methodology}

To answer the research question related to the factors that affect secondary school students' academic achievement in Chemistry, we conducted a literature search to collect the related literature. Sixty-one studies were obtained; some of them were not related to our investigation; and those which did not answer the research question were excluded; we remained with 13 studies. The selection of studies was based on the year of publication, and on the language. These studies were published in English, and in the years of 2011 and 2021.

Since the duty of the researchers was to communicate knowledge, we opted to analyze the written literature by searching through Google Scholar, ERIC, Web of science, and related Websites as the database during the period of the total lockdown caused by the Covid-19 pandemic. This was motivated by the fact that researchers reported the literature analysis as an approach that could be used to support and communicate the knowledge; and that in such a situation, the validity of the study should be well managed (Mohammed \& Ahmed, 2019). According to Onwuegbuzie et al. (2012), analyzing literature is researching written materials, studying a text, interpreting its meanings, and exploring why the author made certain choices. The reviewed studies are presented in Table 1, showing 8 categories, of which 17 factors were explored. 


\begin{tabular}{|c|c|c|c|c|c|c|}
\hline $\mathbf{S} / \mathbf{N}$ & $\begin{array}{l}\text { Category of } \\
\text { factors }\end{array}$ & Factors & Author (s) & $\begin{array}{l}\text { Research } \\
\text { design }\end{array}$ & \begin{tabular}{|c|} 
Results and/or \\
statistical significance
\end{tabular} & Effect \\
\hline \multirow[t]{3}{*}{1} & \multirow[t]{3}{*}{ School factors } & $\begin{array}{l}\text { Laboratory } \\
\text { adequacy and } \\
\text { instructional } \\
\text { materials }\end{array}$ & $\begin{array}{l}\text { (Banyoko et } \\
\text { al., 2016) }\end{array}$ & $\begin{array}{l}\text { Cross- } \\
\text { sectional } \\
\text { survey } \\
\text { research } \\
\text { design }\end{array}$ & \begin{tabular}{|c|} 
Science laboratory, \\
instructional materials \\
and laboratory \\
adequacy had a \\
probability value less \\
than $0.05(\mathrm{P}<0.05)$ \\
\end{tabular} & Yes (+) \\
\hline & & $\begin{array}{c}\text { Influence of } \\
\text { school } \\
\text { characteristics }\end{array}$ & $\begin{array}{l}\text { Anditi et al., } \\
2013\end{array}$ & & $\begin{array}{c}\text { Single-sex school } \\
\text { learners performed } \\
\text { significantly better than } \\
\text { their colleagues from } \\
\text { co-educational schools }\end{array}$ & Yes (+) \\
\hline & & $\begin{array}{l}\text { Chemistry } \\
\text { practicals }\end{array}$ & $\begin{array}{l}\text { (Mwangi \& } \\
\text { Kibui, 2017) }\end{array}$ & \begin{tabular}{|c|} 
Quasi- \\
experiment \\
al of the \\
pretest- \\
post-test \\
design
\end{tabular} & $\begin{array}{c}\text { The experimental and } \\
\text { control groups differ } \\
\text { significantly in the } \\
\text { post-test }\end{array}$ & Yes (+) \\
\hline 2 & Content area & Subject content & $\begin{array}{c}\text { (Onuekwusi, } \\
\text { 2015) }\end{array}$ & $\begin{array}{c}\text { Instrumenta } \\
\text { tion and } \\
\text { survey } \\
\text { research }\end{array}$ & $\begin{array}{c}\text { There was a significant } \\
\text { influence on the } \\
\text { achievement }\end{array}$ & Yes (+) \\
\hline 3 & Self-efficacy & $\begin{array}{l}\text { Willingness to } \\
\text { succeed }\end{array}$ & $\begin{array}{l}\text { (Baanu \& } \\
\text { Oyelekan, } \\
2016)\end{array}$ & $\begin{array}{c}\text { Descriptive } \\
\text { survey }\end{array}$ & \begin{tabular}{|l|} 
There was no \\
significant relationship \\
between self-efficacy \\
and students' \\
achievement
\end{tabular} & No \\
\hline \multirow[t]{4}{*}{4} & \multirow[t]{4}{*}{$\begin{array}{l}\text { Teachers and } \\
\text { students' } \\
\text { factors }\end{array}$} & $\begin{array}{l}\text { Shortage of } \\
\text { trained teachers } \\
\text { and lack of } \\
\text { proficiency in } \\
\text { the language of } \\
\text { instruction }\end{array}$ & $\begin{array}{c}\text { (Hassan et al., } \\
\text { 2017) }\end{array}$ & $\begin{array}{c}\text { Descriptive } \\
\text { survey }\end{array}$ & $\begin{array}{c}\text { More than half of the } \\
\text { teachers }(64 \%) \text { were not } \\
\text { qualified; and they saw } \\
\text { this as a contributing } \\
\text { factor to the low level } \\
\text { of achievement }\end{array}$ & No (-) \\
\hline & & $\begin{array}{c}\text { Teachers' } \\
\text { qualifications }\end{array}$ & (Ajayi, 2017b) & \multirow[t]{2}{*}{$\begin{array}{l}\text { Ex-post } \\
\text { facto } \\
\text { research } \\
\text { design }\end{array}$} & $\begin{array}{c}\text { There is a correlation } \\
\text { between learners' } \\
\text { achievements and } \\
\text { teachers' qualifications } \\
(\mathrm{r}=0.72)\end{array}$ & Yes (+) \\
\hline & & $\begin{array}{c}\text { Teachers' } \\
\text { content } \\
\text { knowledge, and } \\
\text { experience }\end{array}$ & (Ajayi, 2017b) & & \begin{tabular}{|c|} 
There is a correlation \\
between educators' \\
content knowledge \\
with learners' \\
achievements $(\mathrm{r}=0.89) ;$ \\
and a correlation \\
between educators' \\
years of teaching \\
experience and \\
learners' achievements \\
$(\mathrm{r}=0.51)$ \\
\end{tabular} & Yes (+) \\
\hline & & $\begin{array}{c}\text { Teachers' } \\
\text { perception of } \\
\text { their learners' } \\
\text { ability } \\
\end{array}$ & $\begin{array}{c}\text { (Ogembo et } \\
\text { al., 2015) }\end{array}$ & $\begin{array}{c}\text { Questionnai } \\
\text { re and } \\
\text { interview } \\
\text { schedule }\end{array}$ & \begin{tabular}{|c|} 
The negative \\
perceptions of \\
Chemistry instructors \\
towards their learners'
\end{tabular} & No (-) \\
\hline
\end{tabular}




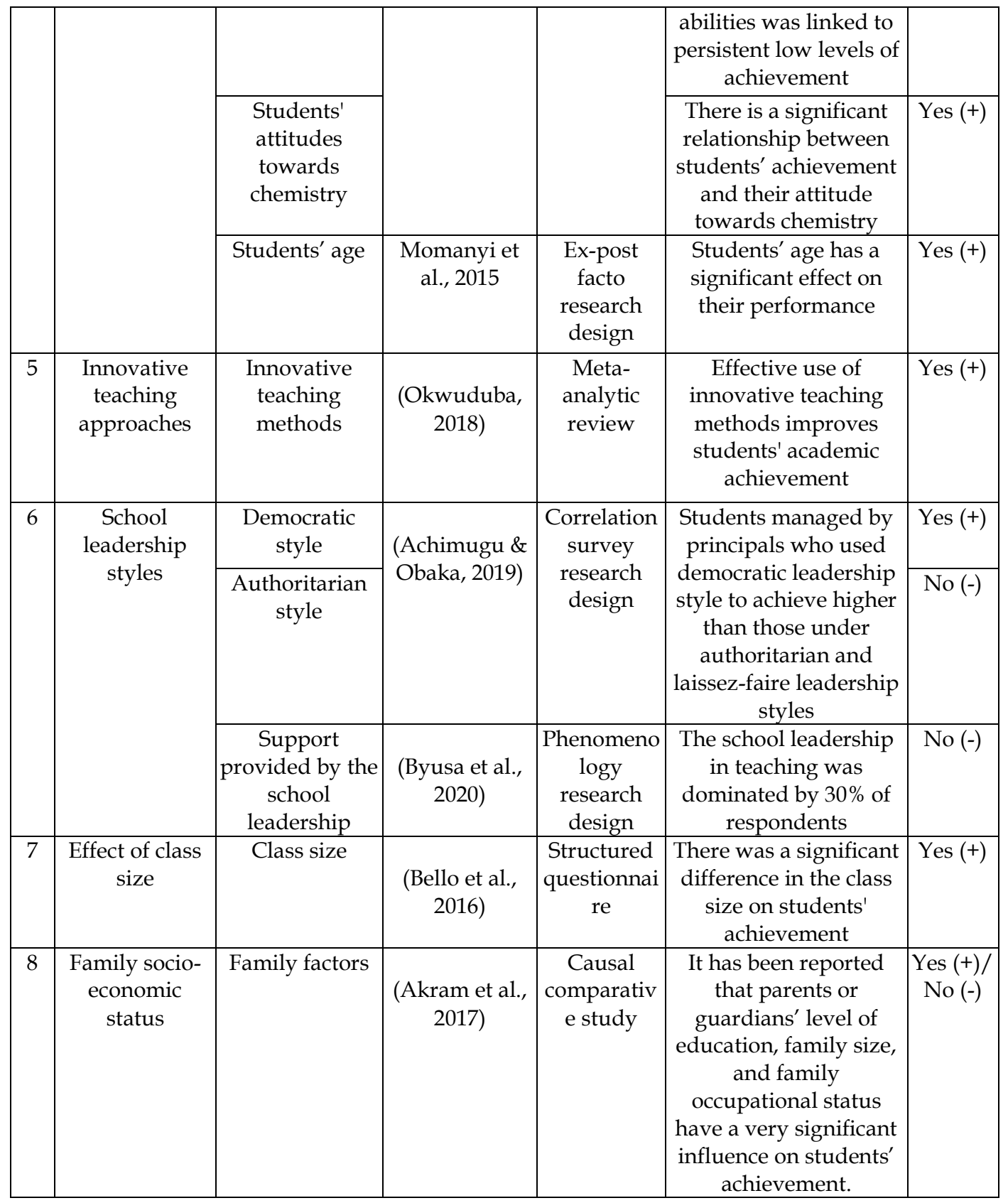

\section{Results and Discussion}

The reviewed literature places the emphasis on eight categories that include seventeen factors influencing students' achievement in chemistry. Table 1 displays the factors studied in one or more of the reviewed studies; and their significance level on students' academic achievement in Chemistry were grouped according to authors, research design, results, or statistical level of significance and effect. Among the 8 categories, there are 17 factors where 12 were perceived to affect the students' academic achievement positively; and that 3 affect their achievement negatively; while 2 showed no significant influence on the achievement of students in Chemistry as a subject. 
According to Banyoko et al., (2016) laboratory adequacy and the school's materials influence the students' achievements. Also, Anditi et al. (2013) revealed that there is an influence of school characteristics on students' achievement in Chemistry, and that learners from single-sex schools performed significantly better than their colleagues from co-educational schools. A study by Achimugu and Obaka (2019) discovered that students under the leadership of democratic principals perform better than their colleagues under authoritative and laissezfaire principals; a discovery which accords with that of Paul and Toyin (2017) that the most influential leadership style on the performance of students is democratic. Moreover, Ahosani et al., 2017 reported that students' achievements are influenced by the way school leaders focus on the core business of teaching and learning, and how they inspire the school community, which is the same as that which Karadag (2020) reported.

A research project conducted by Momanyi et al., (2015) reported that students' age has a significant effect on their academic performance; this agrees with the findings of Akram et al. (2017), who revealed that adult students were less interested in chemistry than younger students. The same author reported that the content area influences students' academic achievements.

Teachers are central to any consideration in schools. Educators are the pillars on which the instructive processes hang. According to Vivian (2018), educators can influence the teaching-learning results; since they regulate the delivery of educational instruction.

Consequently, teacher-related factors are among the factors that influence students' achievement; this has been reported in a study by Muzaffargarh and Ameeq (2018) that the absenteeism of teachers hinders students' achievement for the reason that their absence from school affects the students' progress and concentration on the lessons; their use of lecture-teaching methods, the way they perceive their learners' ability and their qualification also influence the achievement of students (Ajayi, 2017b; Mahdi, 2014; Ogembo et al., 2015; Okwuduba, 2018).

The availability and use of teaching and learning materials, like textbooks in the sciences and laboratory equipment, affect the effectiveness of the lessons and the learners' motivation. It makes the teacher's lesson more concrete; and students learn more easily by doing. Thus, students' achievement is highly improved by the availability and good use of teaching and learning materials; and students enjoy an activity-based lesson; and they then participate actively in the course (Banyoko et al., 2016; Ejidike \& Oyelana, 2015; Tolsdorf et al., 2018).

Students' attitude towards Chemistry was reported to influence their academic achievement (Ogembo et al., 2015). Attitude is another important learning concept, which denotes an interest in studying a particular subject. Students with an affirmative attitude to a chemical subject spend more time learning it, without becoming bored (Mahdi, 2014). Students may have a negative attitude towards Chemistry, and take it as difficult to learn; because they did not get any guidance 
from their schools; but if done successfully with good teaching methods, it becomes a motivational task to enhance their attitude towards Chemistry as a subject (Akram et al., 2017; Yitbarek, 2011).

It is also true that home influence (parents' or guardians' level of education, family size, and family occupational status) in the education of children is identified as a very significant variable that has the potential for influencing directly or indirectly students' academic achievement; and these factors have a great impact on their success (Akram et al., 2017). Parental contribution in students' education begins at home by providing basic needs, suitable learning experience, care, and a constructive attitude towards school and Chemistry as a subject; this involvement can be seen in six areas, which are: parenting, learning at home, cooperating, volunteering, decision-making, and partnership with the community of the school.

In addition, children who are economically advantaged and those whose parents have a good level of education receive enough stimulation at home, thereby enhancing their academic achievement (Bunujevac \& Durisic, 2017).

\section{Conclusion and Recommendations}

From the review study conducted in exploring those factors influencing students' academic achievement, it was found that among the important factors which are grouped in eight categories are: school factors; content area; teachers and students' factors; innovative teaching approaches; effect of class size; family socioeconomic status; and leadership styles.

Students' scholastic achievement in Chemistry has been seen to depend on the good process of instruction by applying innovative teaching methods that take into account learners' prior knowledge in a conducive environment with motivated teachers. Misconceptions of students can be attributed to the absence of interest in a subject; inappropriate instruction methods employed by teachers; and these can be stopped by updating teachers through advanced education and regularly planned pieces of training. A list of factors that hinder students' achievement in chemistry can be regulated by the good application of innovative instructional strategies by educators, good school leadership styles, availability of teaching and learning materials combined with good participation of parents or guardians in the learning of their children. The role of innovative teaching strategies and motivated teachers is of crucial importance in Chemistry education.

In addition to the above, the application of innovative teaching strategies for the remedies of misconceptions in teaching and learning chemistry may be combined with the application of teaching principles to capture learners' intention to know; since they are complementary and interdependent in a Chemistry classroom; because sometimes they are present in the same lesson; and they all contribute to its success and effectiveness. In reality, when teachers use concrete examples (Concretization), they keep the learners' attention (motivation) and they encourage the learners to use the newly acquired skills at school and at their homes in their everyday lives (transfer). Moreover, the teacher calls upon the 
learners' participation by applying cooperative learning (cooperation), or by asking them to do work individually (activities + individualization). They can choose tasks that are better adapted to the learners' level (progression); and they can start with what the learners are familiar with, and then move on to the unfamiliar; so that the understanding of the learners is thereby boosted. When they have enough time, all the seven principles are incorporated in a single lesson; and this makes the teaching and learning of Chemistry so much more successful. They can also work interdependently; and one complements another, for more pedagogical effectiveness. Failure to use one of the above principles affects the effectiveness of the entire lesson.

Chemistry as a science that studies the composition and the properties of substances with the changes it experiences; it could be taught in a favorable milieu with willing learners and favorably disposed educators. Furthermore, in Chemistry instruction, students need to be given the opportunity for a hands-on approach; since it is intended to permit learners to gain meaningful learning, to instruct students' awareness and meaning; to obtain suitable competencies that allow playing their roles in social development. Preconceptions and school-made misconceptions can be identified and discussed with in-service and pre-service teachers; and to equip them with innovative teaching methods, to be applied in Chemistry instruction effectively. Teachers or facilitators could learn how to choose suitable teaching methods; and they could introduce new lessons to capture the students' desire to know.

Also, the crucial role of school leadership in Chemistry education should be taken into account by planning and monitoring students' and teachers' achievement goals (performance contract); planning the school-based in-service training and in collaboration with parents, different education stakeholders could provide all the needed learning facilities accordingly. During the period of total lockdown by Covid-19, while we conducted this research, the participants could not be met; and some online alternatives had not yet been trained; consequently, there is a need for further research on the effects of identified innovative teaching strategies, in order to improve students' achievement in different science-related subjects and contexts.

\section{References}

Achimugu, L., \& Obaka, H. (2019). Influence of Principals' Leadership Styles on Senior Secondary School Students' Achievement in Chemistry. Science Education International, 30(2), 92-96. https:// doi.org/10.33828/sei.v30.i2.2

Adu-Gyamfi, K., Ampiah, J. G., \& Agyei, D. D. (2020). Participatory teaching and learning approach: A framework for teaching redox reactions at high school level. International Journal of Education and Practice, 8(1), 106-120. https://doi.org/10.18488/journal.61.2020.81.106.120

Ahosani, A. A., Singh, S. K., Nahyan M.T. A., (2017). Role of school leadership and climate in student achievement: The mediating role of parental involvement. International Journal of Education Management. 31(6), 843-851. https://doi.org/10.1108/ijem-052016--0113

Ajayi, O. V. (2017a). Effect of Hands-On Activities on Senior Secondary Chemistry Students Achievement and Retention in Stoichiometry in Zone C of Benue State. 
SSRN Electronic Journal, 2(2), 54-59. https://doi.org/10.2139/ssrn.2992803

Ajayi, O. V. (2017b). Relationship between Teachers ' content knowledge , qualifications , experience and Students' achievement in Chemistry. Scholarly Journal of education. 6(1),14-20.

Akram, T. M., Ijaz, A., \& Ikram, H. (2017). Exploring the Factors Responsible for Declining Students' Interest in Chemistry. International Journal of Information and Education Technology, 7(2), 88-94. https://doi.org/10.18178/ijiet.2017.7.2.847

Amedu, O. I., \& Gudi, K. C. (2017). Attitude of Students towards Cooperative Learning in Some Selected Secondary Schools in Nasarawa State. Journal of Education and Practice, 8(10), 29-34.

Amineh, R. J., \& Asl, H. D. (2015). Review of constructivism and social constructivism. Journal of Social Sciences, Literature and Languages, 1(1), 9-16.

Anditi, Z. O., Okere, I. O., \& Muchiri, D. R. (2013). Influence of School Characteristics on the Achievement of Secondary School Chemistry Students in the Cognitive Science process Skill of Evaluation in Kenya. European Journal of Educational Research. 2(4), 171-183.

Baanu, T. F., \& Oyelekan, O. S. (2016). Self-Efficacy and Chemistry Students' Academic Achievement in Senior Secondary Schools in North-Central, Nigeria. Malaysian Online Journal of Educational Sciences, 4(1), 43-52.

Banyoko, O. O., Gbadamosi, M. R., Abidu, K. A., Moyib, O. K., \& Lawal, O. A. (2016). School factors as determinant of senior secondary school school factors as determinant of senior secondary school students ' academic achievement in chemistry. Journal of Science Education and Research. 1(2), 83-93

Bello, A., Omwirhiren, E. M., D, E. P., \& Anderson, F. E. (2016). Effect of Class Size and Students ' Attitude on Academic Performance in Chemistry at Demonstration Secondary School.6(1),1-6. https://doi.org/10.9790/7388-06120106

Broman, K., Bernholt, S., \& Parchmann, I. (2018). Using model-based scaffolds to support students solving context-based Chemistry problems. International Journal of Science Education, 1-22. https://doi.org/10.1080/09500693.2018.1470350

Bunujevac, M., \& Durisic, M. (2017). Parental Involvement as an Important Factor for Successful Education. CEPS Journal, 7(3), 137-153.

Byusa, E., Kampire, E., \& Mwesigye, A. R. (2020). Ways School Leaders Support the Teaching of Chemistry. African Journal of Educational Studies in Mathematics and Sciences, 16(1), 63-72. https://doi.org/10.4314/ajesms.v16i1.5

Dwyer, A. O., \& Childs, P. E. (2017). Who says Organic Chemistry is difficult? Exploring perspectives and perceptions. Eurasian Journal of Mathematics Science and Technology Education, 13(7), 3599-3620. https://doi.org/10.12973/eurasia.2017.00748a

Ejidike, I. P., \& Oyelana, A. A. (2015). Factors Influencing Effective Teaching of Chemistry: A Case Study of Some Selected High Schools in Buffalo City Metropolitan Municipality, Eastern Cape Province, South Africa. International Journal of Educational Sciences, 8(3), 605-617. https://doi.org/10.1080/09751122.2015.11890282

Farias, R. F. De. (2017). Hybrid orbitals notation : some misconceptions in a hybrid orbitals notation: some misconceptions in an undergraduate Chemistry course. African Journal of Chemical Education, 7(1), 1-8.

Farzaneh, N., \& Nejadansari, D. (2014). Students' attitude towards using cooperative learning for teaching reading comprehension. Theory and Practice in Language Studies, 4(2), 287-292. https:/ / doi.org/10.4304/tpls.4.2.287-292

Graulich, N. (2015). Research and Practice The tip of the iceberg in Organic Chemistry classes : how do students deal with the invisible? Chemistry Education Research and 
Practice, 16, 9-21. https://doi.org/10.1039/C4RP00165F

Hanson, R. (2017). Enhancing teacher trainees' understanding about Cchemical reactions and equations. International Journal of Academic Research and Reflection, 5(6), 57-68.

Harcourt, P. (2017). Effect of Inquiry Teaching Strategy on Academic Achievement of Senior Secondary School Chemistry Students in Okrika Local Government Area, 3(12), 9-14.

Hassan, A. A., Ali, H. I., Salum, A. A., Kassim, A. M., Elmoge, Y. N., \& Amour, A. A. (2017). Factors Affecting Students' Performance in Chemistry: Case Study in Zanzibar Secondary Schools. International Journal of Social, Behavioral, Educational, Economic, Business and Industrial Engineering, 9(9), 1-9.

Imomotimi, E. (2013). Some Factors Affecting the Performance of Secondary School Students in Chemistry , A Kolokuma / Opokuma Study . Journal of Education and Practice, 4(7), 2-6.

Kara, M. (2018). A Systematic Literature Review: Constructivism in Multidisciplinary Learning Environments. International Journal of Academic Research in Education, October, 19-26. https://doi.org/10.17985/ijare.520666

Karadag, E., (2020). The effect of educational leadership on students' achievement: a crosscultural meta-analysis research on studies between 2008 and 2018. Asian Pacific Education Review, 21, 49-64. https://doi.org/10.1007/s12564-019-09612-1

Luoga, N. E., Ndunguru, P. A., \& Mkoma, S. L. (2013). Research Article H igh school students ' misconception s about colligative properties in Chemistry. Tanzania Journal of Natural and Applied Sciences, 4(1), 575-581.

Mahdi, G. J. (2014). Students' Attitudes towards Chemistry: an Examination of Choices and Preferences. American Journal of Educational Research, 2(6), 351-356. https://doi.org/10.12691/education-2-6-3

Mari, J. S., \& Gumel, S. A. (2014). Effects of Jigsaw Model of Cooperative Learning on SelfEfficacy and Achievement in Chemistry among Concrete and Formal Reasoners in Colleges of Education in Nigeria. International Journal of Information and Education Technology, 5(3), 196-199. https://doi.org/10.7763/ijiet.2015.v5.501

Momanyi, J. M., Too, J., \& Simiyu, C. (2015). Effect of Students' Age on Academic Motivation and Academic Performance among high School Students in Kenya. Asian Journal of Education and e-learning, 3(5), 337-342.

Mohammed, S. I., \& Ahmed, M. (2019). Problems of Academic Literature Review and Writing: the Way Forward. Journal of Management Sciences, 16(5), 11-26

Murniningsih, Muna, K., \& Irawati, R. K. (2020). Analysis of misconceptions by four tier tests in Electrochemistry, case study on students of the Chemistry education study program UIN Antasari Banjarmasin. Journal of Physics: Conference Series, 1440(1). https://doi.org/10.1088/1742-6596/1440/1/012008

Muzaffargarh, P. D., \& Ameeq, M. (2018). Impact of Teaches'r Absenteeism on Students' Achievement: A Case of South Impact of Teacher Absenteeism on Students' Achievement: A Case of South Punjab District Muzaffargarh

Mwangi, J. T., \& Kibui, A. W. (2017). Effect of ChemistrynPracticals on Students' Performance in Chemistry in Public Secondary Schools of Machakos and Nairobi Countries in Kenya. International Journal of Science and Research, 6(8), 586-588. http://doi.org/10.21275/ART20175884

Nkemakolam, O. E., Chinelo, O. F., \& Jane, M. C. (2018). Effect of Computer Simulations on Secondary School Students ' Academic Achievements in Chemistry in Anambra State. 4(4), 284-289. https://doi.org/10.20448/journal.522.2018.44.284.289

O'Dwyer, A., \& Childs, P. (2015). Organic Chemistry in Action! What Is the Reaction? Journal of Chemical Education, 92(7), 1159-1170. https://doi.org/10.1021/ed5006163

Ogembo, J. O., Otanga, H., \& Yaki, R. N. (2015). Students' and Teachers' Attitudes and 
Performance in Chemistry in Secondary Schools in Kwale County, Kenya. Global Journal of Interdisciplinary Social Sciences, 4(3), 39-43.

Okwuduba, E. (2018). Effect of Teaching Methods on Students ' Academic Effect of Teaching Methods on Students' Academic Performance in Chemistry in Nigeria : Meta-Analytic Review. Bulgarian Journal of Science and Education Policy(BJSEP) Tion, 12(2), 2-18.

Onuekwusi, C. (2015). Influence Of Age And Content Area On Students' Achievement In Chemistry. Journal of Education, 3(1), 1-7.

Onwuegbuzie, A. J., Leech, N. L., \& Collins, K. M. T. (2012). Qualitative analysis techniques for the review of the literature. Qualitative Report, 17(28), 1-28.

Paul, M. H. J., \& Toyin, M. A. O. (2017). Investigation on the Influence of Leadership Styles on Students' Academic Performance in Selected Secondary Schools: A Case Study of Gasabo District, Kigali, Rwanda. IOSR Journal of Research \& Method in Education (IOSRJRME), 7(2), 18-26. https:// doi.org/10.9790/7388-0702011826

Shadrec, M., Enunuwe, O. C., Town, C., \& Africa, S. (2018). Comparative effect of two problem-solving instructional strategies on students' achievement in stoichiometry. African Journal of Chemical Education, 8(2), 34-48.

Sibomana, A., Karegeya, C., \& Sentongo, J. (2021). Students' conceptual understanding of Organic Chemistry and classroom implications in the Rwandan perspective: A literature review. African Journal of Educational Studies in Mathematics and Sciences 16(2). https://dx.doi.org/10.4314/ajesms.v16i.2.2

Stojanovska, M. I., Petruševski, V. M., \& Šoptrajanov, B. T. (2012). Addresing students' misconceptions concerning chemical reactions and symbolic representations. Chemistry, 21(6), 829-852.

Tenaw, Y. A. (2015). Effective strategies for teaching Chemistry. International Journal of Education Research and Reviews, 3(3), 78-84.

Tolsdorf, Y., Kousa, P., Markic, S., \& Aksela, M. (2018). Learning to Teach at Heterogeneous and Diverse Chemistry Classes - Methods for University Chemistry Teacher Training Courses. EURASIA Journal of Mathematics, Science and Technology Education, 14(10). https:// doi.org/10.29333/ejmste/93377

Tümay, H. (2016). Reconsidering learning difficulties and misconceptions in Chemistry: Emergence in Chemistry and its implications for Chemical education. Chemistry Education Research and Practice, 17(2), 229-245.

Üce, M., \& Ceyhan, İ. (2019). Misconception in Chemistry Education and Practices to Eliminate Them : Literature Analysis. 7(3), 202-208. https://doi.org/10.11114/jets.v7i3.3990

Vivian, I. E. (2018). A review on factors affecting chemistry students performance. International Journal of current Research in Chemistry and Pharmaceutical Sciences, 5(5), 40-43. http://dx.doi.org/10.22192/ijrcps.2018.05.05.008

Vogelzang, J., Admiraal, W. F., \& Van Driel, J. H. (2020). A teacher perspective on Scrum methodology in secondary Chemistry education. Chemistry Education Research and Practice, 21(1), 237-249. https://doi.org/10.1039/c9rp00111e

Worldbank. (2016). An overview of the progressive science initiative and progressive mathematics initiative (PSI-PMI) and its implementation in the Gambia. World Bank.

Yitbarek, S. (2011). Chemical reaction: diagnosis and towards remedy of misconceptions. African Journal of Educational Studies in Mathematics and Sciences, 1(1).

Yüksel, M. (2014). A Study of the Prediction of Academic Achievement in the Chemistry Course. Education and Science, 39(173), 354-365.

Yusuf, S. D. (2014). Effects of Collaborative Learning on Chemistry Students' Academic Achievement and Anxiety Level in Balancing Chemical Equations in Secondary School in Katsina Metropolis, Nigeria. Journal of Education and Vocational Reseach, 5(2), 43-48. https://doi.org/10.22610/jevr.v5i2.151 